\title{
Effects of Great Lakes Water Loading upon Glacial Isostatic Adjustment and Lake History
}

Author(s): James A. Clark, Deborah J. Zylstra, Kevin M. Befus

Source: Journal of Great Lakes Research, 33(3):627-641. 2007.

Published By: International Association for Great Lakes Research

DOI: http://dx.doi.org/10.3394/0380-1330(2007)33[627:EOGLWL]2.0.CO;2

URL: http://www.bioone.org/doi/full/10.3394/0380-1330\%282007\%2933\%5B627\%3AEOGLWL $\% 5 \mathrm{D} 2.0 . \mathrm{CO} \% 3 \mathrm{~B} 2$

BioOne (www.bioone.org) is a nonprofit, online aggregation of core research in the biological, ecological, and environmental sciences. BioOne provides a sustainable online platform for over 170 journals and books published by nonprofit societies, associations, museums, institutions, and presses.

Your use of this PDF, the BioOne Web site, and all posted and associated content indicates your acceptance of BioOne's Terms of Use, available at www.bioone.org/page/terms_of_use.

Usage of BioOne content is strictly limited to personal, educational, and non-commercial use. Commercial inquiries or rights and permissions requests should be directed to the individual publisher as copyright holder. 
J. Great Lakes Res. 33:627-641

Internat. Assoc. Great Lakes Res., 2007

\title{
Effects of Great Lakes Water Loading upon Glacial Isostatic Adjustment and Lake History
}

\author{
James A. Clark*, Deborah J. Zylstra, and Kevin M. Befus \\ Department of Geology and Environmental Science \\ Wheaton College \\ Wheaton, Illinois 60187
}

\begin{abstract}
Over the last century geological studies of the ancestral Great Lakes have confirmed that the large surface load of the Laurentide ice sheet deformed the region causing tilting of ancient lake shorelines. Models of this glacial isostatic adjustment mechanism have promoted understanding of this process but have only included ice sheet loads as the source of earth deformation in the region. We describe a method, utilizing a model of glacial isostatic adjustment combined with GIS, that recreates the paleohydrology of the Great Lakes. Predictions include the extent of late glacial, postglacial, and Holocene lakes and their associated outlets and bathymetries. This predicted history of the Great Lakes is similar to that obtained from a century of detailed field studies but our method uses only the present digital elevation model, a prescribed ice sheet chronology, and an assumed earth viscoelastic rheology. Ancient lake bathymetry predictions provide an estimate of water loads associated with each lake. The effect of these lake loads upon vertical deformation of the Great Lakes region is shown to be small, less than $15 \mathrm{~m}$, but not insignificant when compared to approximately $150 \mathrm{~m}$ of deformation forced by ice and ocean loads. Maximum lake-induced deformation is centered upon Lake Superior where water depths were greatest. Where topography is low relief, prediction of shoreline locations should include the lake loading effect as well as the ice and ocean loads.
\end{abstract}

INDEX WORDS: Great Lakes, glacial isostasy, earth deformation, lake history, water loading.

\section{INTRODUCTION}

In studies of isostatic adjustment, numerical calculations have demonstrated that surface loads from ice sheet fluctuations are the dominant source affecting the entire planet (Cathles 1975; Wu and Peltier 1983, 1984; Nunn and Peltier 2001). Additional refinement to these calculations include the effects of meltwater loading of the ocean floor (Farrell and Clark 1976, Milne and Mitrovica 1996, Milne et al. 1999, Lambeck et al. 2003) and this effect, though small when compared to regions once covered by ice, is nevertheless significant at regions distant from the ice sheets yet close to the ocean (e.g., Cathles 1975, Clark et al. 1978, Clark and Bloom 1979, Lambeck and Nakada 1990, Peltier 1994). Where melting ice sheets were replaced by ocean water flooding into the vacated region, water loads partially replaced ice loads requiring additional refinement of the model (Clark and Lingle 1979, Milne et al. 1999). Although several studies have

\footnotetext{
${ }^{*}$ Corresponding author. E-mail: James.A.Clark@wheaton.edu
}

sought to model the isostatic adjustment of the Great Lakes region (Gutenberg 1933, Broecker 1966, Brotchie and Silvester 1969, Clark et al. 1990, Clark et al. 1994, Tushingham and Peltier 1992, Lewis et al. 2005) none have explicitly evaluated the effects of freshwater loading as the proglacial lakes formed during ice retreat and basins filled with water during postglacial times. If the ice sheets were thick in the region, exceeding 1,000 $\mathrm{m}$ as suggested by Hughes et al. (1981) and Colgan (1999), the lake loading effects would be minimal compared to the effects of the ice sheet load. But other studies suggest the ice sheet was thin and dynamic over the Great Lakes region (Fisher et al. 1985, Clark 1992, Clark et al. 1994) and therefore it is important to evaluate the impact of lake loading upon the glacial isostatic adjustment process.

\section{THEORY AND METHOD}

The theory describing glacial isostatic adjustment with self-consistent ocean loading is well estab- 
lished. If the earth behaves as a linear viscoelastic radially stratified self-gravitating sphere under the influence of surface loads, then the time-dependent sea-level change, $s$, anywhere on the earth's surface resulting from ice sheet melting can be calculated (Farrell and Clark 1976):

$$
\begin{aligned}
s(r, t)= & \frac{1}{g}\left[\iint_{\text {ccean }} \rho_{w} s\left(r^{\prime}, t\right) G^{e}\left(r-r^{\prime}\right) d r^{\prime}+\right. \\
& \iint_{i c e} \rho_{1} I\left(r^{\prime}, t\right) G^{e}\left(r-r^{\prime}\right) d r^{\prime}+ \\
& \left.\sum_{i=1}^{n} \iint_{\text {ocean \&ice }} L_{i}\left(r^{\prime}\right) G^{h v}\left(r-r^{\prime}, t-t_{i}\right) d r^{\prime}\right]-K_{e}(t)-K_{c}(t)
\end{aligned}
$$

with $r$ and $r$ ' representing locations on the earth's surface, $t$ the time, $I$ the ice sheet thickness, $L_{i}$ the incremental load change of either ice or water load in a given time interval, and $G^{e}$ and $G^{h v}$ the elastic and viscous "Heaviside" potential perturbation Green's functions for the earth structure of interest. The constants $g, \rho_{w}$, and $\rho_{I}$ are the acceleration due to gravity, density of sea water, and density of ice, respectively. Although $G^{e}$ is constrained well by seismic data, $G^{h v}$ requires knowledge of the Earth's viscosity structure (Peltier 1974). Although viscosity is not known with certainty (e.g., Sabadini et al. 1991), the VM2 viscosity model of Peltier (1998, 1999) has been shown to adequately explain isostatic adjustment throughout much of the planet and so we have adopted the VM2 viscosity structure in our model. The elastic lithosphere is assumed to be 120 $\mathrm{km}$ thick. The first two terms of Equation (1) give the immediate elastic earth response to water and ice loads. The third term is the slow viscous response resulting from all previous load changes. Finally, $K_{e}$ and $K_{c}$ insure that water mass is conserved as ice sheets melt and their meltwater flows into the ocean. $K_{e}$ is the oceanwide average sea-level rise usually called the eustatic sea-level rise and is defined as:

$$
K_{e}(t)=\frac{\rho_{1}}{\rho_{w} A_{o}} \iint_{i c e} I\left(r^{\prime}, t\right) d r^{\prime}
$$

with $A_{o}$ the area of the oceans. Because oceans are irregularly distributed over the globe and because the average potential perturbation deformation of the Green's functions is non-zero, $K_{c}$ must also be included to account for the oceanwide average earth deformation forced by the loads. This term can be calculated from:

$$
\begin{aligned}
K_{c}(t)= & \frac{1}{g A_{o}}\left\{\int \int _ { \text { ocean } } d r ^ { \prime \prime } \left[\iint_{\text {ocean }} \rho_{w} s\left(r^{\prime}, t\right) G^{e}\left(r^{\prime}-r^{\prime \prime}\right) d r^{\prime}+\right.\right. \\
& \left.\left.\iint_{i c e} \rho_{I} I\left(r^{\prime}, t\right) G^{e}\left(r^{\prime}-r^{\prime \prime}\right) d r^{\prime}\right]\right\} \\
& +\frac{1}{g A_{o}}\left\{\iint_{\text {ocean }} d r^{\prime \prime} \sum_{i=1}^{n} \iint_{\text {ocean \&ice }} L_{i}\left(r^{\prime}\right) G^{h v}\left(r^{\prime}-r^{\prime \prime}, t-t_{i}\right) d r^{\prime}\right\}
\end{aligned}
$$

Equation (1) can be solved numerically for realistic ice and ocean configurations if the ice-sheet history and earth viscosity structure are known. For efficient calculation, the loads are assumed to be applied over a grid of cells, each loaded uniformly and with loads that change only at 1000-year intervals. We use Equation (1) initially to determine the ocean loads affecting the earth given prescribed ice sheet loads. Once $s$ is determined we then use Equation (2) to calculate the deformation, $D_{I}(r, t)$, relative to the geoid, at 10,000 points over the Great Lakes region and use these predictions to deform the present day digital elevation model (DEM), resulting in a paleo-DEM.

$$
\begin{aligned}
D_{I}(r, t)= & \frac{1}{g}\left[\iint_{\text {ccean }} \rho_{w} s\left(r^{\prime}, t\right) G^{e}\left(r-r^{\prime}\right) d r^{\prime}+\right. \\
& \iint_{i c e} \rho_{I} I\left(r^{\prime}, t\right) G^{e}\left(r-r^{\prime}\right) d r^{\prime}+ \\
& \left.\sum_{i=1}^{n} \iint_{\text {ocean \&ice }} L_{i}\left(r^{\prime}\right) G^{h v}\left(r-r^{\prime}, t-t_{i}\right) d r^{\prime}\right]
\end{aligned}
$$

Geographic Information System (GIS) methods, briefly described in the next section, are then used to determine the bathymetry of any resulting proglacial lakes and hence the water depth, $w(r, t)$, of the lakes as they filled or drained. The effect upon earth deformation of these freshwater loads is:

$$
\begin{array}{r}
D_{W}(r, t)=\frac{1}{g}\left[\iint_{\text {lakes }} \rho_{f} w\left(r^{\prime}, t\right) G^{e}\left(r-r^{\prime}\right) d r^{\prime}+\right. \\
\left.\sum_{i=1}^{n} \iint_{\text {lakes }} W_{i}\left(r^{\prime}\right) G^{h v}\left(r-r^{\prime}, t-t_{i}\right) d r^{\prime}\right]
\end{array}
$$

with $\rho_{f}$ the density of fresh water and $W_{i}$ the incremental lake load associated with filling of earlier lakes formed at time $t_{i}$. The explicit linearity of the problem insures that the total effect of ice, ocean, 


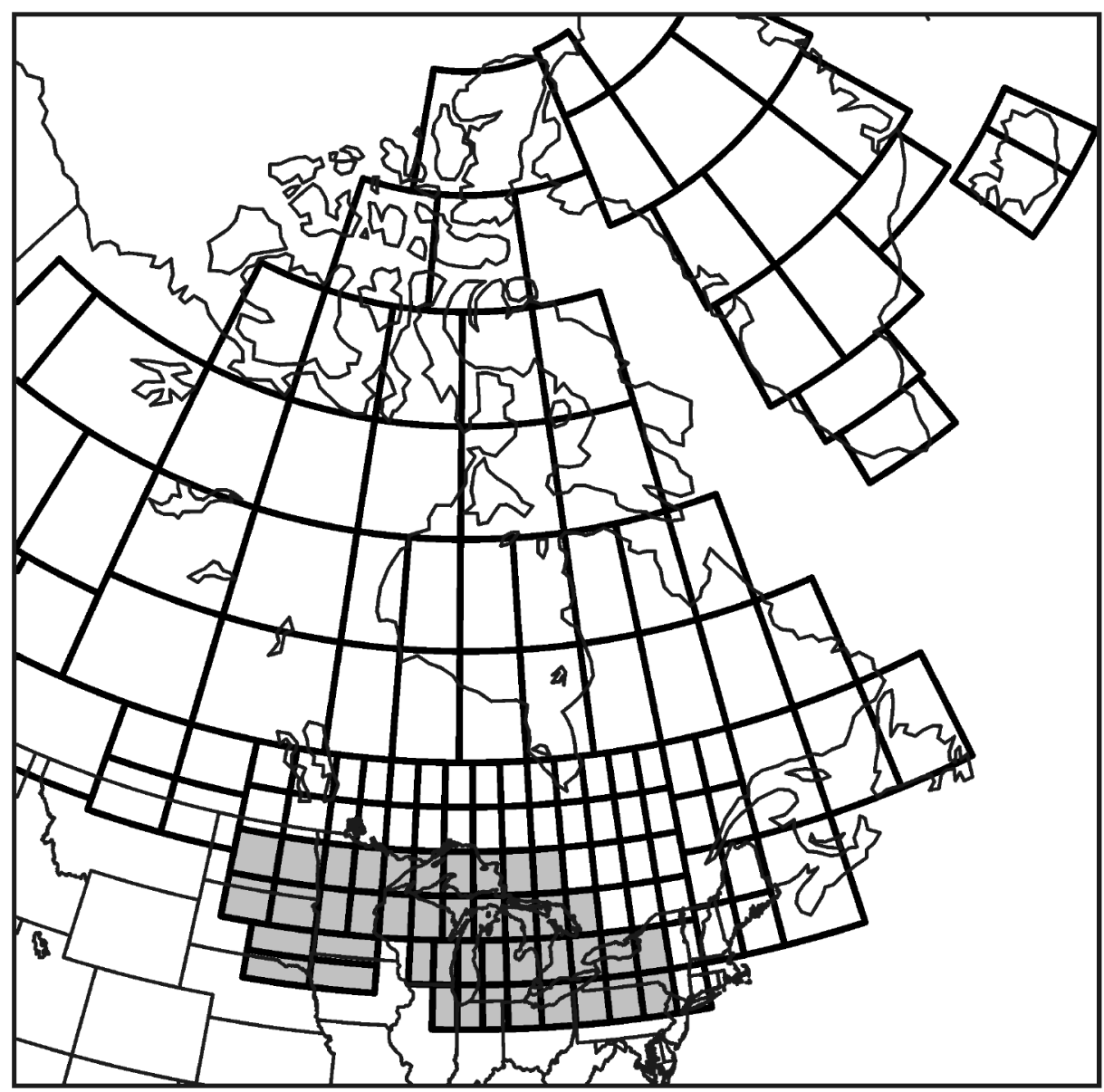

FIG. 1. Grid used to approximate ice sheet loading. Loading is assumed constant over each cell but may vary among cells and through time. Time-dependent loads change only at 1,000-year intervals. ICE-3G ice thickness is converted to a calendar year chronology, and used everywhere, except over the shaded region where the thickness is $40 \%$ of ICE$3 G$ thickness. Similar ice grids represent ice sheets in other regions of the world and a 350 cell grid also approximates meltwater loads over the ocean.

and lake loading is determined from the algebraic sum of $D_{I}(r, t)$ and $D_{W}(r, t)$. As in the ocean loading case, deformation from lake loads will slightly alter the lake bathymetry and hence the lake loads. We have not included this second order feedback effect in our study.

\section{Prediction of Late-glacial and Postglacial Lakes in the Great Lakes Region}

The entire history of the lakes in the Great Lakes region can be simulated because the paleo-DEM at any time is calculated, and the ice sheet extent during those times is known from field studies. The
GIS extensions, Terraflow implemented in GRASS or Hydrology in ArcGIS's Spatial Analyst, can calculate a DEM where all closed depressions are filled. Subtraction of this "filled DEM" from the paleo-DEM yields the distribution and bathymetry of the ancient lakes. In the present study, a DEM with a coarse resolution of $1,000 \mathrm{~m}$ is used to demonstrate the method, simplified from the $90 \mathrm{~m}$ resolution available from the Shuttle Radar Topography Mission (SRTM) data set. The SRTM data do not include Great Lakes bathymetry essential for our study so present bathymetry of the Great Lakes from the National Geophysical Data Center 


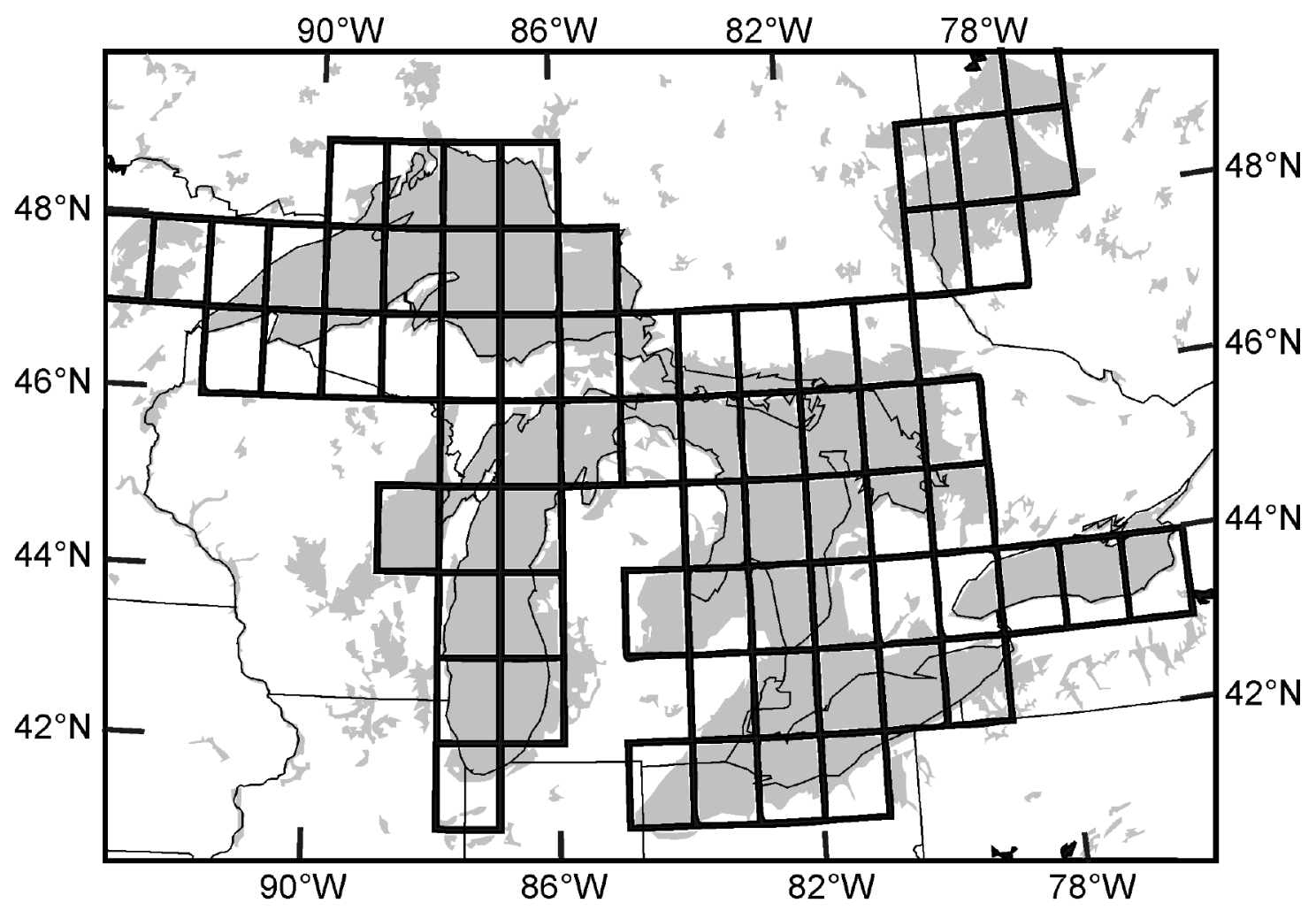

FIG. 2. Lake loading is approximated by a grid of 71 cells. Regions predicted to be covered by freshwater at any time in the past are shown in gray.

(NGDC) of the U.S. National Oceanic and Atmospheric Administration (NOAA) was added to the DEM. This data set was not complete and so Lake Superior bathymetry was provided by the Large Lakes Observatory of the University of Minnesota (personal communication, Colman and $\mathrm{Yu}$ ).

Furthermore, the rivers that drained the lakes and the outlets of the lakes can also be determined. Each outlet is located using the Terraflow or Hydrology GIS tools to generate a map of flow accumulation that gives the number of DEM cells contributing surface water to each cell of the map. If the predicted lake extent is expanded by one raster cell, the cell along the expanded lake margin with the greatest accumulation value is the outlet. Therefore the surface paleo-hydrology of the Great Lakes can be simulated using the present DEM, bathymetry data and the ice sheet extent.

Grid cells that we use to represent the portion of the ice loads over North America are shown in Figure 1. Lake water loading occurred well beyond the present extent of the Great Lakes, and Figure 2 shows the spatial distribution of predicted lakes that occurred at any time during the past 30,000 years. The 71 cells that represent the water load associated with proglacial and postglacial lakes are also given in that figure. Once the ice sheet history is prescribed and the viscoelastic properties of the earth are defined, it is possible to determine the amount of deformation, the paleo-DEM, and the size of the resulting lakes.

\section{Ice and Water Loads}

The ice sheet thickness chronology used in our study is similar to the ICE-3G history proposed by Tushingham and Peltier (1991). Although more recent work has improved upon the ICE-3G history (Peltier 1994, 2004), that work did not report ice sheet thicknesses, only ice sheet elevations, and so the required loading history was not available for our study. But it is now possible to retrieve ICE-5G thicknesses (Peltier and Fairbanks 2006) and so subsequent work will employ that improved ice sheet thickness chronology. The thickness chronology used in the present study departs from the ICE- 


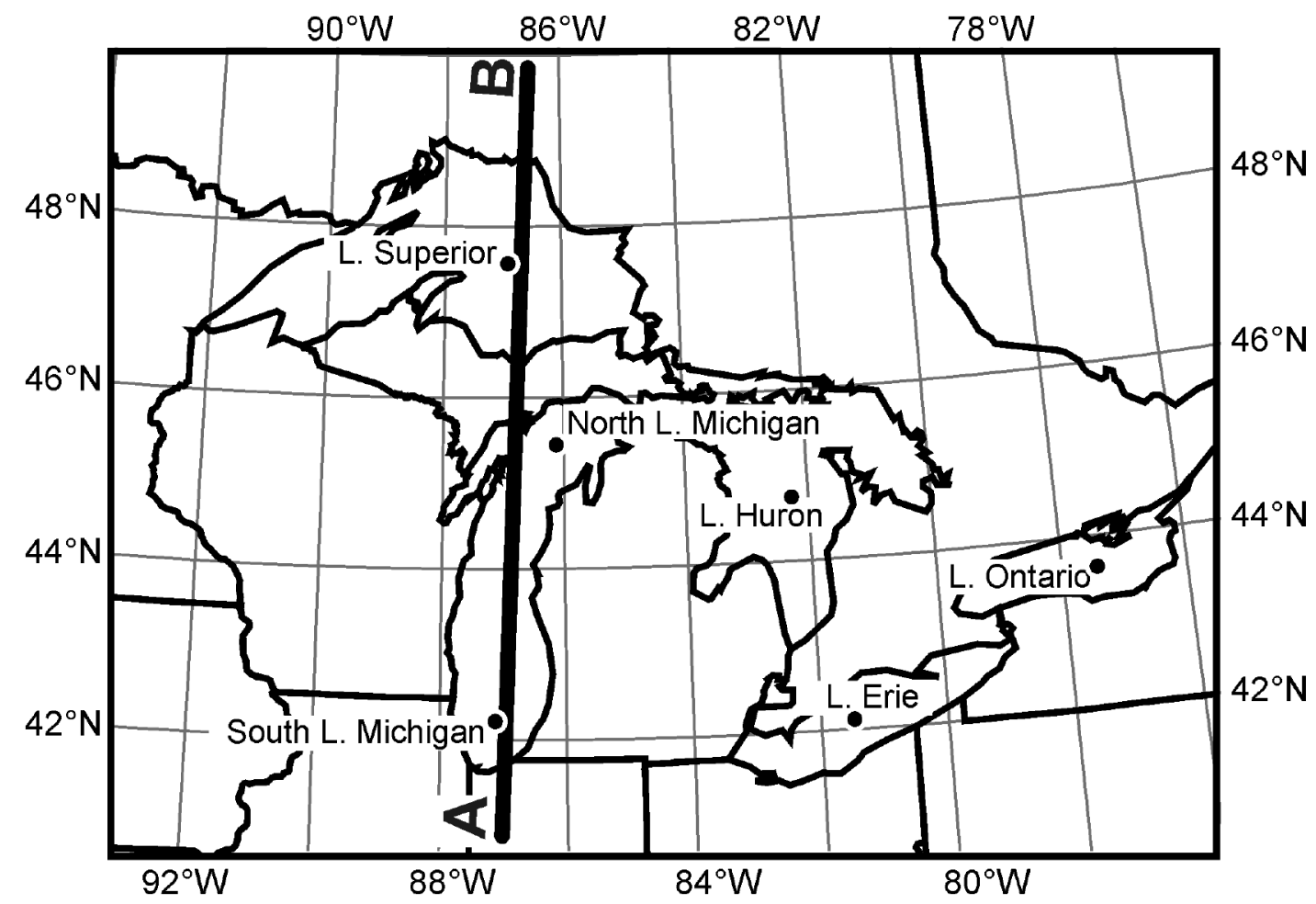

FIG. 3. Transect giving location of ice thickness profiles of Figure 4. Points are locations where individual lakes are subsequently characterized for water depth and deformation.

$3 \mathrm{G}$ history in that the original radiocarbon chronology was converted to calendar years using the table provided by Fairbanks et al. (2005). Because the model requires ice thickness input at exact 1,000year intervals the calibrated ICE-3G thickness chronology could not be used. To obtain thicknesses at the required 1,000-year interval the calibrated ICE-3G values were interpolated using cubic spline methods. Furthermore the ICE-3G thicknesses were reduced to $40 \%$ of the reported thickness over the Great Lakes region (Fig. 1) to best fit observed tilting of glacial Lake Oshkosh in eastern Wisconsin. Ice thickness is not known prior to the glacial maximum so we have assumed the thickness 30,000 calendar years ago was half of its maximum thickness and that it was in isostatic equilibrium at that time. Our ice sheet thickness profile along a transect through Lake Michigan (Fig. 3) is therefore "derby-shaped" (Fig. 4a, Boulton et al. 1985). The time-dependent change in ice sheet thickness at six latitudinal locations along this transect is given in Figure $4 \mathrm{~b}$.

Ice marginal positions were those of Dyke (2004), but the age of each has been converted to calendar years from the original radiocarbon years using the Fairbanks et al. (2005) table. The method outlined above resulted in predicted lakes (Fig. 5a-g) at selected time periods given by Dyke (2004) for his maps of ice sheet extent. The predicted lakes are very similar to those determined a century ago (e.g., Spencer 1888, Goldthwaite 1908, Leveret and Taylor 1915), and it is not hard to assign the classic names of those lakes to our predicted lakes. As an example, Figure 6 shows classic lake distributions (Hough 1958) at times of high and low water levels, which can be compared to our lake predictions of Figure 5. But whereas the early work determined lakes through brilliant interpretations of detailed field work, the lakes of Figure 5 were predicted solely through the use of an ice sheet thickness history, an earth rheology, and the present DEM combined with geophysical and hydrological theory. Our predictions also yield the bathymetry of each lake at each time period. An example of this bathymetry at 11,300 calendar years ago is given in Figure 7. The predicted history of water depth at six representative locations (Fig. 3) is given in Figure 8. The southern part of the region became ice-free early and there- 


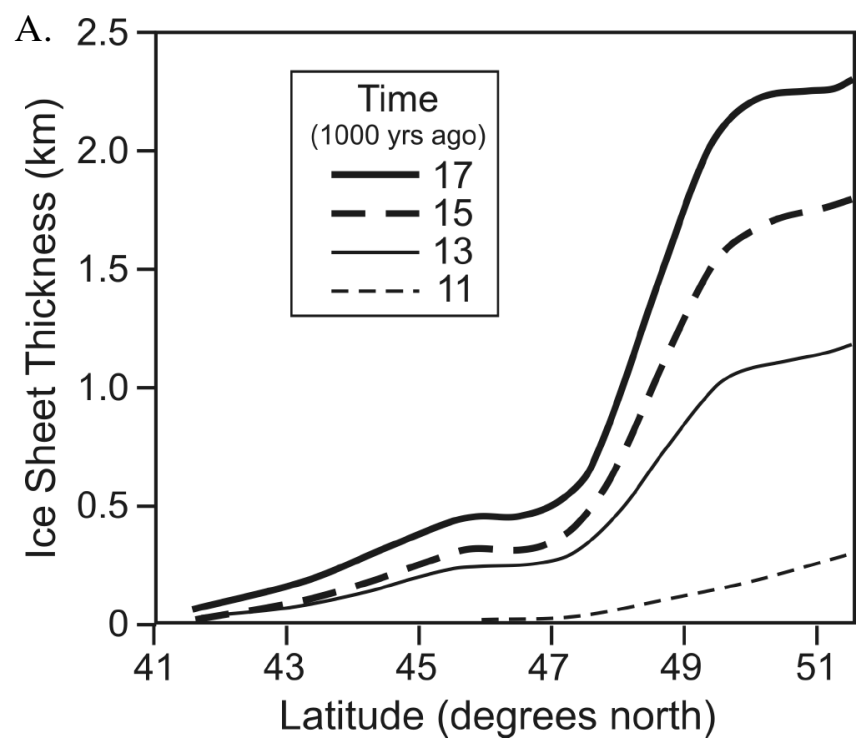

B.

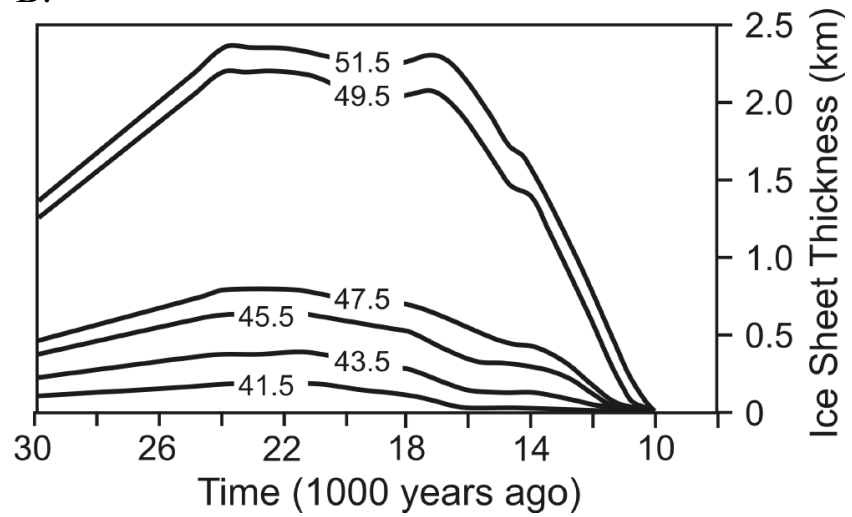

FIG. 4. Assumed ice sheet thickness. a) Profile along transect A-B (Fig. 3) at four times showing the "derby hat" shape of the ice sheet. b) Ice sheet thickness through time at five different latitudes along the transect $A-B$ of Figure 3.

fore experienced water loading well before lakes formed in the northern region. Although most lakes were about $100 \mathrm{~m}$ deep, Lake Superior was about $300 \mathrm{~m}$ deep and so would generate a stronger water loading effect. Dramatic changes in lake levels occurred during late glacial times as the ice sheet margin fluctuated, alternately opening and closing outlets. Once ice left the region, the water loads were largely controlled by glacial isostatic uplift of the controlling North Bay outlet, which gradually caused water levels in Lakes Michigan and Huron to rise. Since 6,000 calendar years ago water loads remained relatively constant.

Although water depth is known in great detail for each proglacial lake, efficient solution of Equation (3) requires that these depths be approximated by a relatively coarse grid (Fig. 2). Common GIS methods (e.g., ArcGIS ZonalStatistics) can determine the time-dependent water depth, $w$, averaged over each cell given the predicted history of lake depths. Equation (3) then yields the effect of lake water loading upon isostatic adjustment. Comparison of the predicted time-dependent vertical movement, relative to present, forced by lake loading, $D_{W}$, to that from ice/ocean loading, $D_{I}$, at the six representative locations indicates that in all cases the water loading effect is much smaller than the ice/ocean effect (Fig. 9a-f). While lakes were loading the crust, the ice sheet was often unloading it. Therefore the response for each type of load is in the opposite sense with lake loading slightly reducing the effect of ice unloading. The relative magnitude of the response depends both upon the duration and magnitude of the lake load, and the thickness of ice. In general the magnitude of isostatic adjustment forced by lake loads is about $10 \%$ of the response caused by ice/ocean loads. Lake water loading always results in crustal subsidence (Fig. 10) because that load is largely maintained until the present. Although water loading over Lake Superior was as much as $300 \mathrm{~m}$, the total subsidence associated with this load is less than $20 \mathrm{~m}$. Such a small amount of deformation can be understood because the spatial extent of Lake Superior is small and therefore the load was largely supported by the $120 \mathrm{~km}$ thick elastic lithosphere. In contrast, the ice sheet, with a much larger extent and thickness, caused the land to subside several hundred meters initially as the ice sheet advanced but then to uplift during glacial retreat (Fig. 9). Subsequent earth relaxation caused large regions of the study area to later subside as a collapsing forebulge migrated northward through the region. During Holocene times and especially in the southern Great Lakes region, forebulge subsidence, which was almost as large in magnitude as the initial uplift, was augmented by subsidence forced by lake water loading.

\section{Isobase and Lake Extent Comparisons}

A spatial representation of deformation relative to present, resulting only from lake loading 11,300 calendar years ago (Fig. 10), indicates that maximum deformation centers on the deepest region of Lake Superior where water loading was greatest. Similar isobase patterns occur at other times and largely in proportion to the time-dependent magni- 
A.

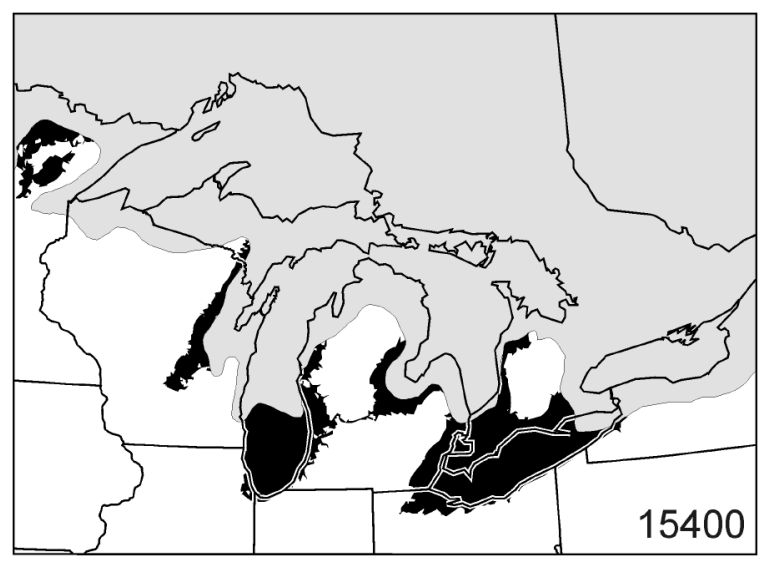

C.

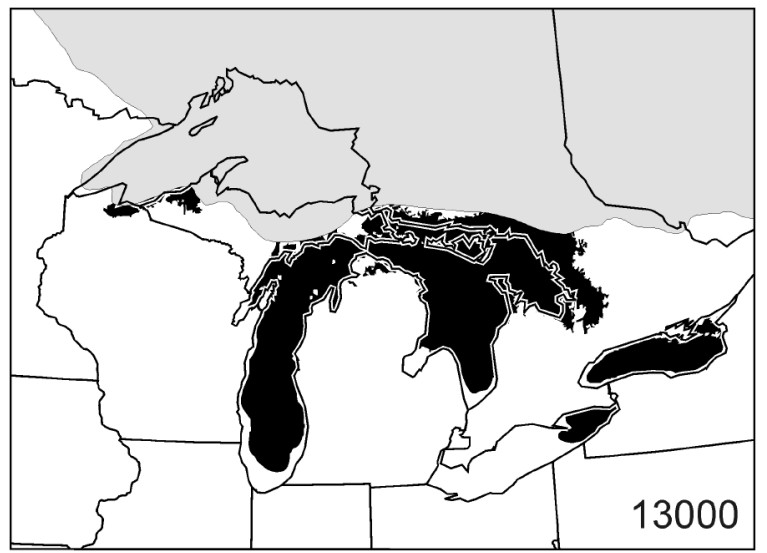

E.

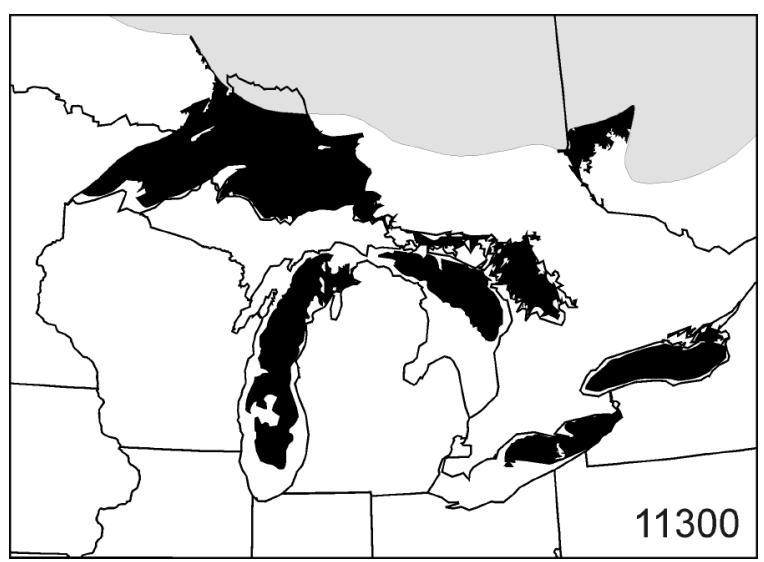

G.

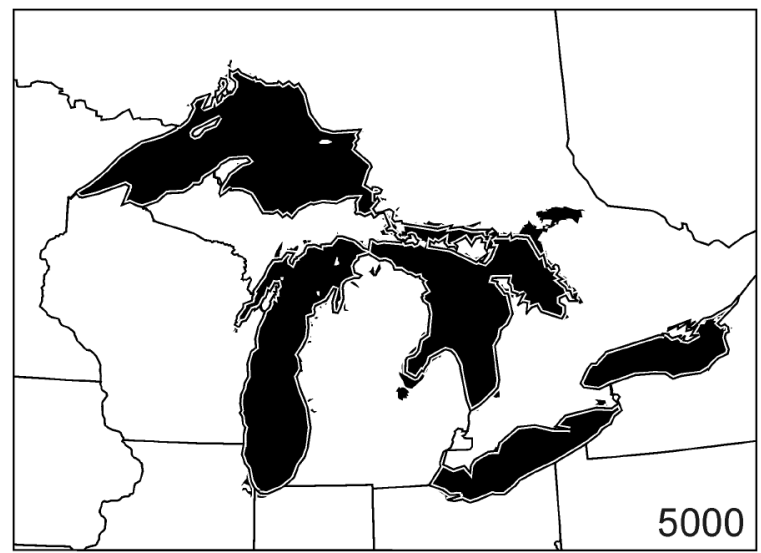

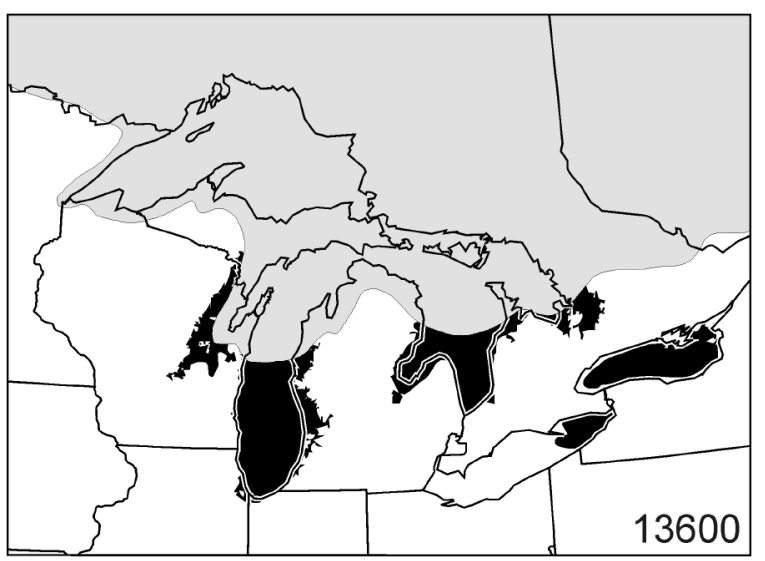

B.

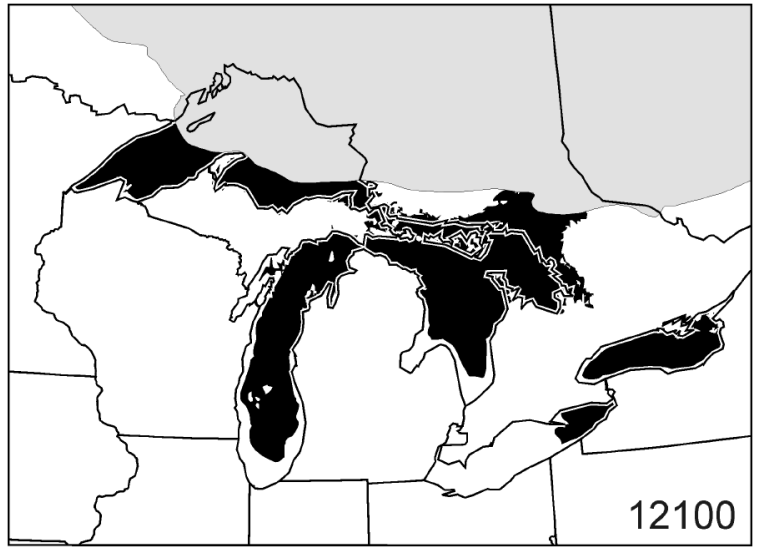

D.

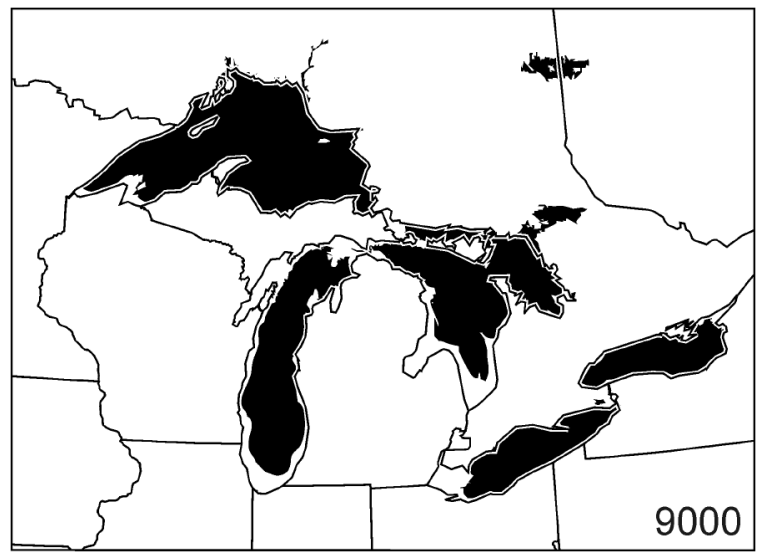

F.

FIG. 5. Snapshots of ice sheet and predicted lake water extent predicted by the model. A to $G$ are for $15,400,13,600,13,000,12,100,11,300$, 9,000 and 5,000 calendar years ago, respectively. Variation in lake extent is controlled by location of ice dams, outlets, and isostatic adjustment. 

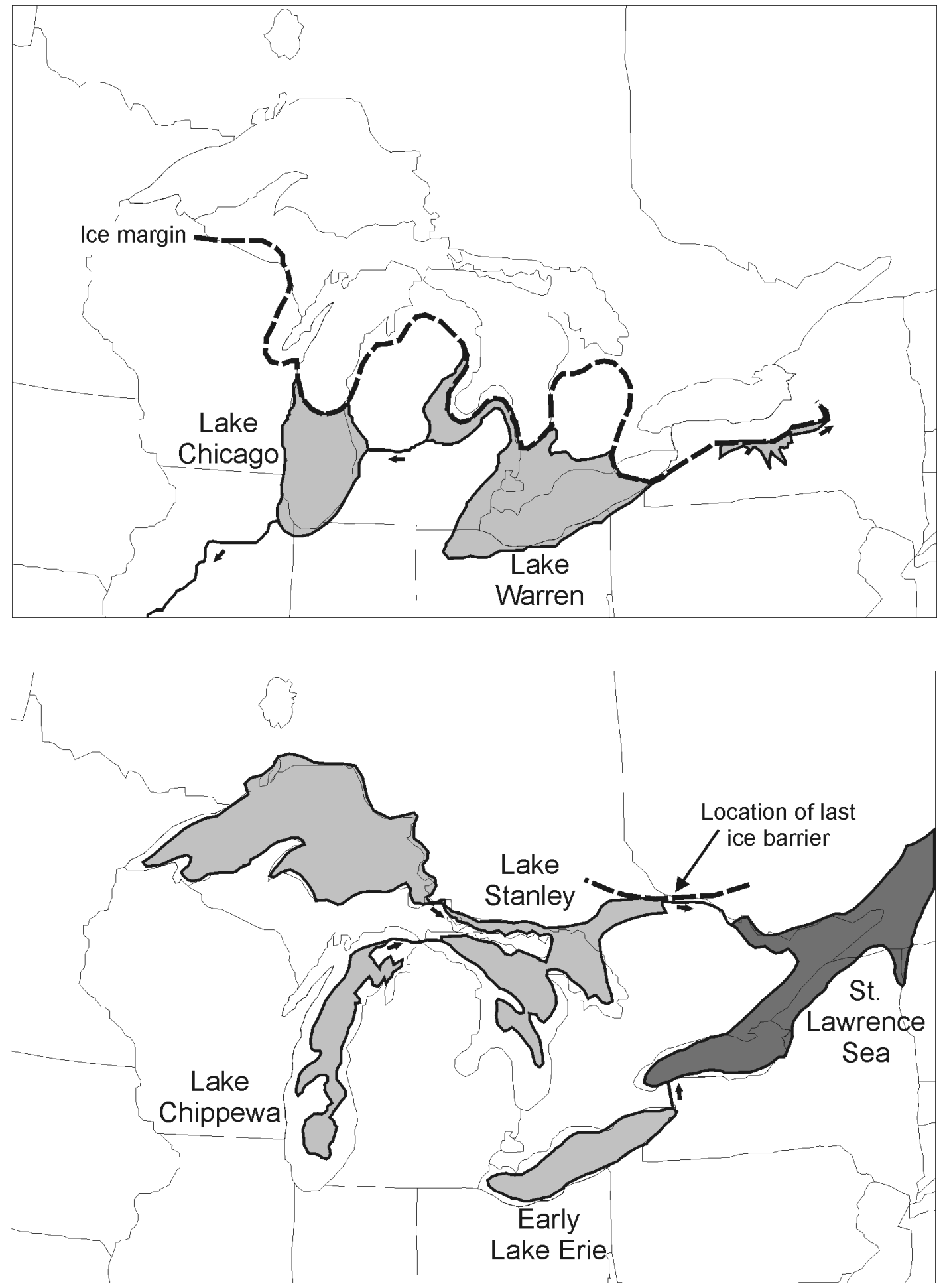

FIG. 6. Examples of lake stage maps summarizing early work for comparison to lake predictions in Figure 5a and 5e (redrawn from Hough 1958). a) "Early post-Port Huron" lakes at approximately 15,400 calendar years ago (page 288). b) "Lowest stage of the Michigan and Huron basins" at approximately 11,300 calendar years ago (page 295). 


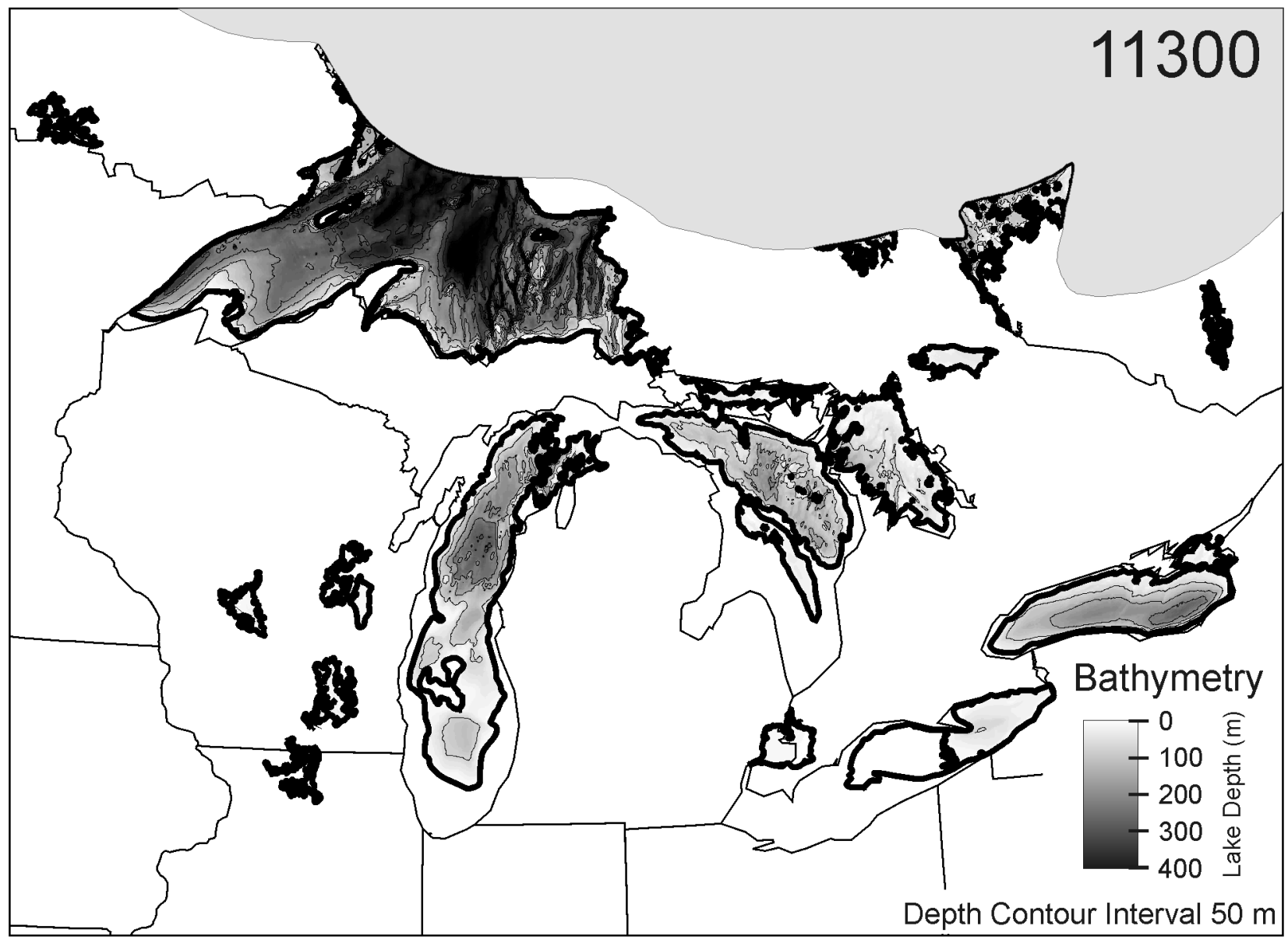

FIG. 7. Predicted lake bathymetry 11,300 calendar years ago. Contour interval is $50 \mathrm{~m}$. Greatest water depth is in Lake Superior basin while lakes formed in the Lake Erie basin were the most shallow.

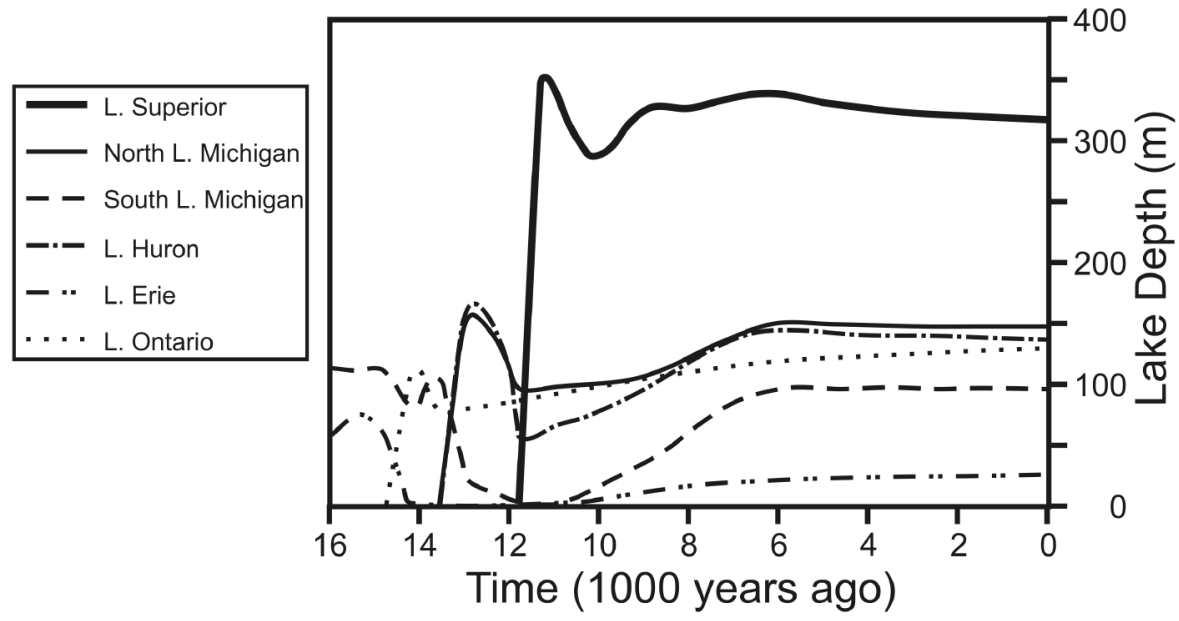

FIG. 8. Predicted change in lake depth at the six locations shown in Figure 3. Ice-covered portions of lakes have zero lake depth. Fluctuations in water depth occured as ice advanced and retreated, blocking and unblocking outlets, and as glacial isostatic adjustment changed outlet elevations. 
A.

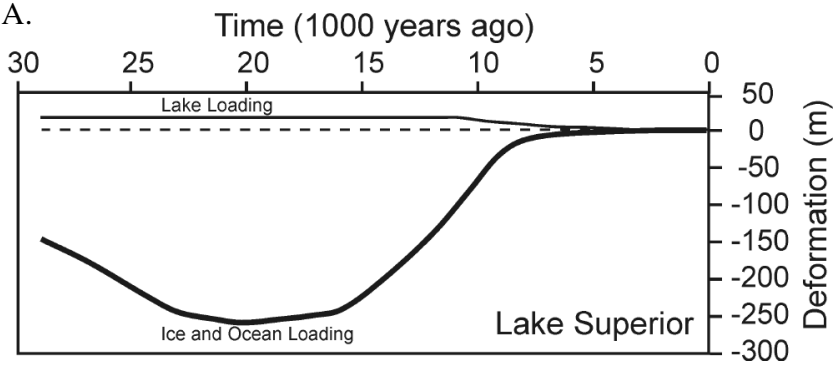

C.

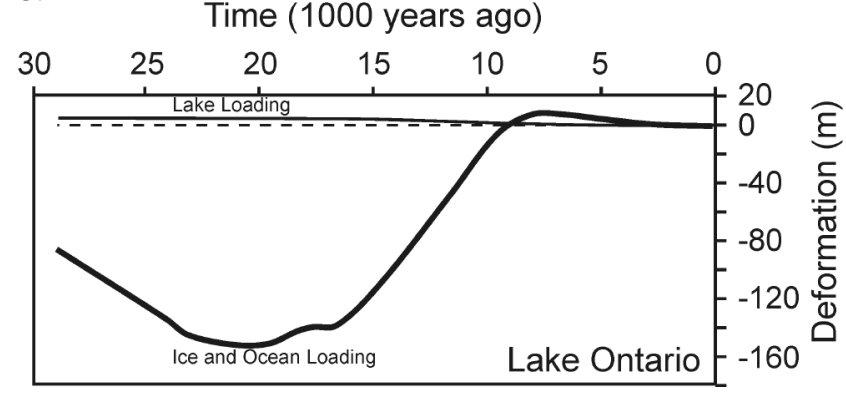

E.

Time (1000 years ago)

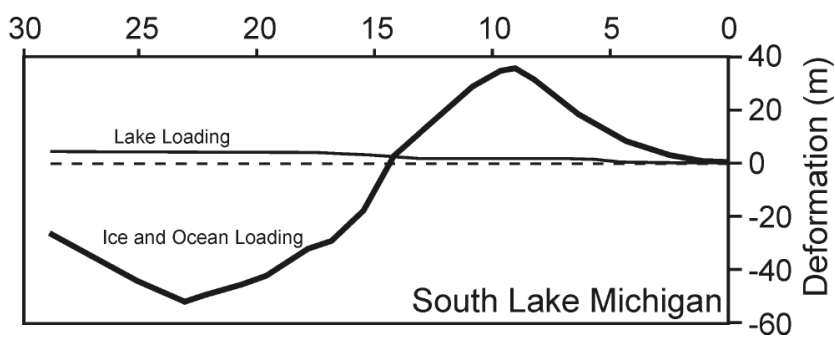

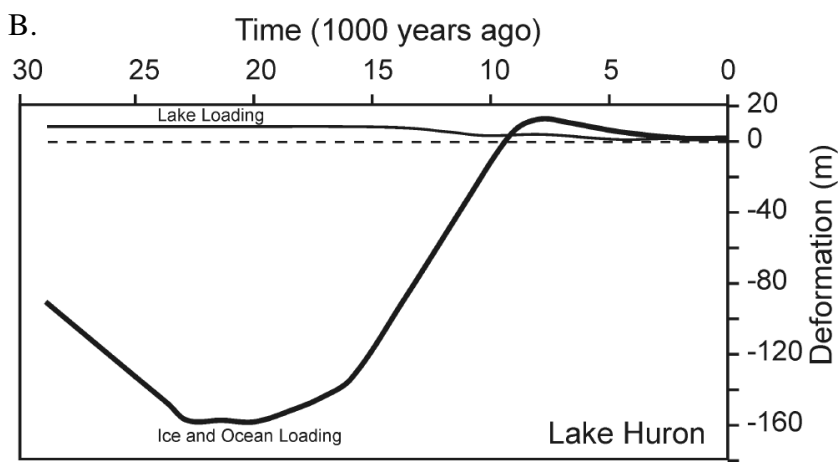

D.

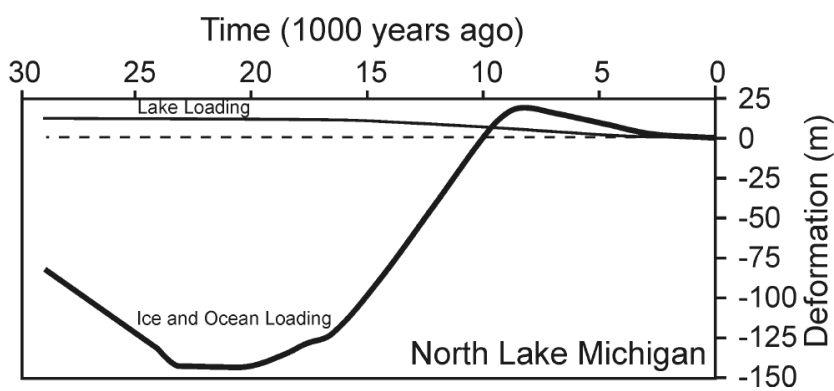

F.

Time (1000 years ago)

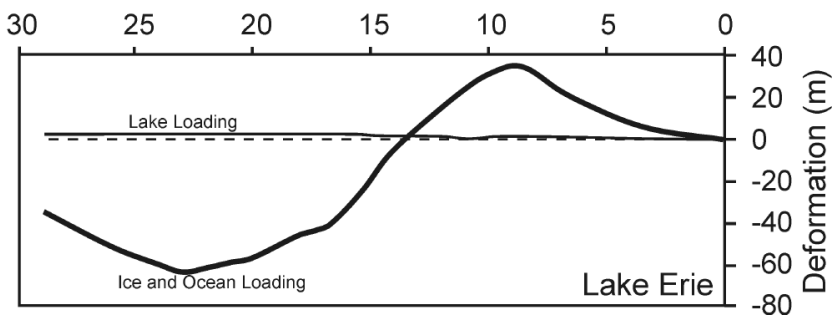

FIG. 9a-f. Comparison of predicted deformation relative to present due to ice sheet and ocean loading $\left(D_{I}\right)$ and to lake loading $\left(D_{W}\right)$ at the six representative locations given in Figure 3. The water loading effect is small when compared to the ice/ocean effect. All cases show subsidence from thickening of ice from 30,000 to 23,000 calendar years ago followed by uplift during ice sheet retreat. In southern regions, a collapsing forebulge causes subsidence during Holocene times. The dashed line is a zero deformation reference line.

tude of deformation shown in Figure 11. To illustrate the effect of lake loading upon total deformation, isobases at 11,300 calendar years ago are given for the case where only ice sheet loading occurred compared to the case where the ice loading is augmented by lake loading (Fig. 12a). The perturbation of the deformation isobases is slight. Similar isobase comparison for 1,000 calendar years ago (Fig. 12b) indicates that only in the southern portion of the Great Lakes do the isobases differ significantly. Assuming the rate of vertical defor- mation has changed little over the past 1,000 years, Figure $12 \mathrm{~b}$ also indicates the predicted present rate of delevelling in $\mathrm{mm} / \mathrm{yr}$ over the Great Lakes region.

Lake Michigan was at a very low stage 11,300 calendar years ago because of drainage through the isostatically depressed North Bay outlet. At this time the level of Lake Michigan was controlled by an outlet at the Straits of Mackinac. In the southern portion of the lake, the predicted lake extent is greater for the case where ice, ocean and lake loading is included 


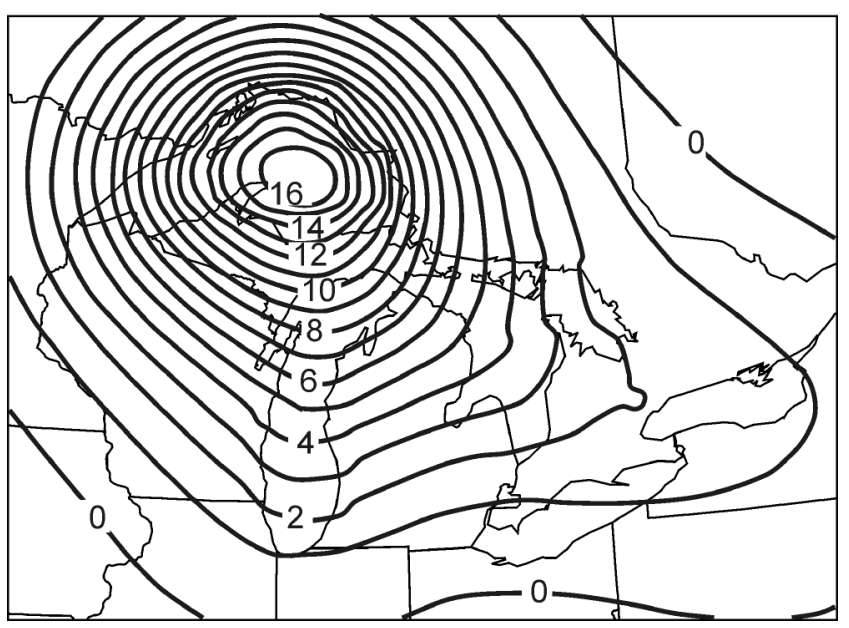

FIG. 10. Predicted spatial variation in earth deformation (meters) relative to present caused by lake loading since 11,300 calendar years ago. Greatest subsidence (about $20 \mathrm{~m}$ ) occurs over Lake Superior where the water depth is greatest (Fig. 7).

than for the case where only ice sheet and ocean loading is used (Fig. 13). On the very flat Lake Michigan floor, the predicted shoreline is displaced horizontally a maximum of $10 \mathrm{~km}$. The amount of deformation caused by water loading between the outlet of that lake and the southern extent of the lake is only $7.5 \mathrm{~m}$. The lake in Figure 13 represents an ex- treme example. Usually the differences in predicted shoreline locations are much smaller.

\section{DISCUSSION}

Because of ice dams and earth deformation the huge Laurentide ice sheet is clearly the most dominant control upon proglacial and late glacial lakes of the Great Lakes region. Water loading by these lakes is of secondary, but not inconsequential, importance. Excellent lake predictions are possible even without inclusion of the lake loading effects, but greater precision is attained when water loading is included. An additional water loading iteration would further improve the prediction. The coarse DEM resolution used in this study is not required, and we have begun a similar analysis with a $100 \mathrm{~m}$ resolution which should provide more precise results than the DEM used in this study. Results of that work will be a detailed comparison of lake predictions to the observed ancient shorelines of the entire Great Lakes region. Erosion of outlets and lake sedimentation has certainly changed the topography of the landscape and will therefore alter the extent and lake bathymetry predicted in our analysis. Adjustment of the present DEM for erosion and sedimentation is possible if the amount and spatial distribution are known. Sedimentation magnitudes can be estimated from coring of ancient lake sediments and high resolution seismic profiles (e.g., Colman et al. 1994). Erosion of outlets must be inferred through careful field work indicating the height and age of shorelines near each outlet.

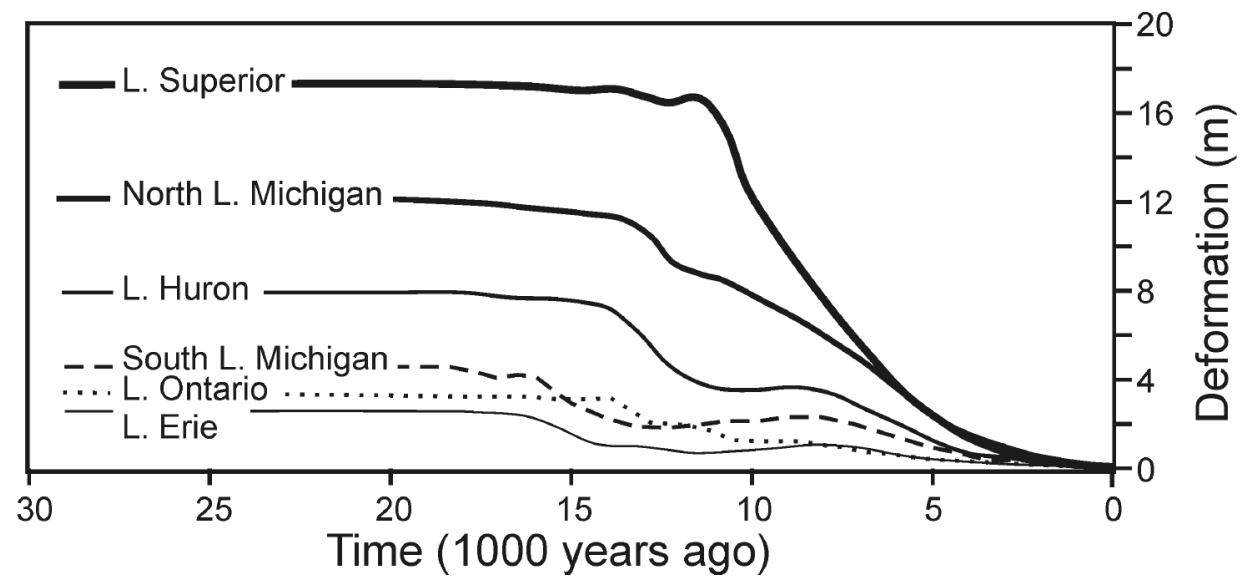

FIG. 11. Predicted Earth deformation (meters) at the six locations of Figure 3 forced solely by lake loading. No deformation occurs while the ice sheet covered the region because water loads did not exist then. Subsequent to ice sheet withdrawal lake loading causes land subsidence. Deformation is relative to present. 

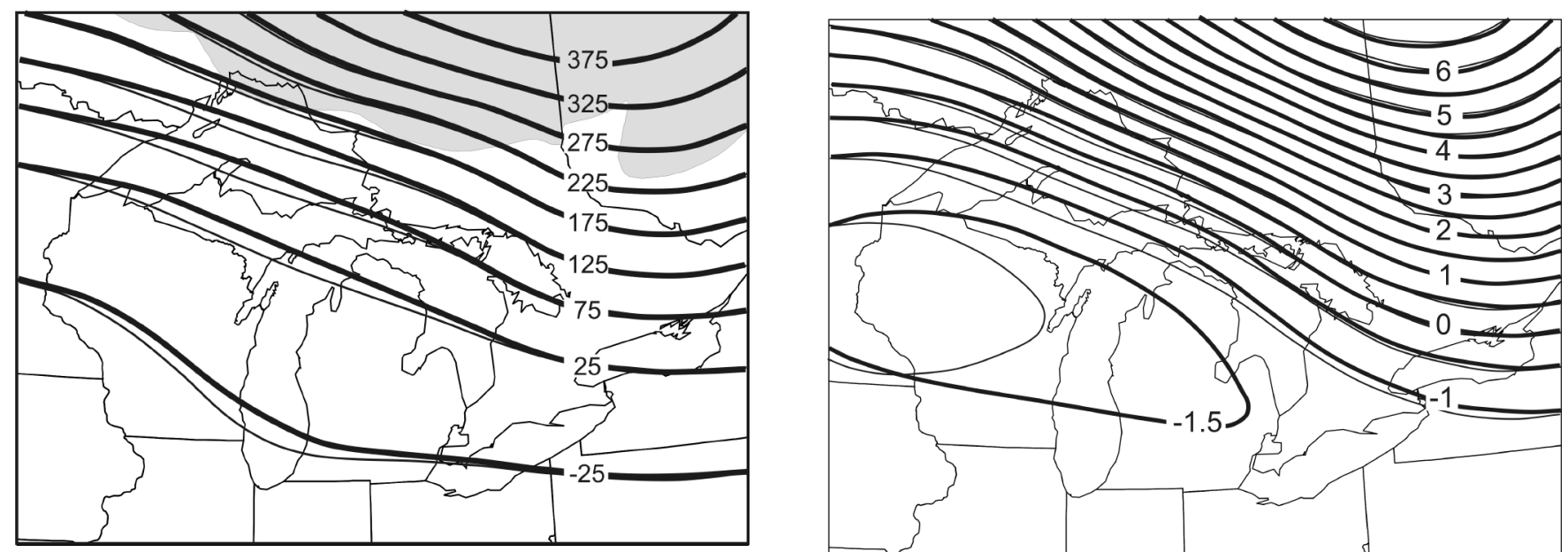

FIG. 12. a) Comparison of predicted deformation isobases (meters) 11,300 calendar years ago for the case where only the icelocean loads are included (thin contours) to the case where lake loading is also included (thick contours). Lake loading causes only slight perturbations in the contours. b) Same as "a" except at 1,000 calendar years ago. Lake loading is most important in the southern Great Lakes region. These contours would also approximate predicted present rate of tilting in mm/year.

In the GIS method of shoreline prediction the closed depressions are filled by the hydrology extensions resulting in lake predictions. However the filling process only brings the lake level up to the level of the lowest point on the outlet and so only incipient discharge occurs at the outlet, an assumption that is certainly incorrect. Precipitation and ice melting must have contributed enormous water volumes to the proglacial lakes, and this water flowed through the spillways. For example, Hansel and Mickelson (1988) believe that the lake surface at the Chicago outlet could have been as much as 15 $\mathrm{m}$ above the outlet floor, if the outlet had been completely eroded to its present configuration during the earliest lake phases. The modern St. Clair river outlet from Lake Huron is approximately $8 \mathrm{~m}$ deep and since 1918 the level of the lake has varied 1.9 m. Our predicted shorelines will therefore parallel the actual shorelines but underestimate those true elevations and therefore the predicted lake loads will be less than the actual freshwater loads.

An additional assumption of these predictions is that sufficient water inflow is available to fill the lakes to the outlet elevation. Evidence suggests that during the lowest lake stands early Holocene water levels were below outlet elevations in the MichiganHuron (Lewis et al. 2005) and Erie (Holcombe et al. 2003) lake basins indicating that severe evaporative draw-down controlled lake levels and not overflow from an outlet. Shorelines from such lakes would be parallel to but below predicted lake levels.
Glacial Lake Agassiz north of the Great Lakes provided a very significant additional freshwater lake load. This lake, with an average depth of 110 $\mathrm{m}$, had an area approximately 1.5 times that of the Great Lakes (Mann et al. 1999). Although it existed only a brief time when compared to the Great Lakes water load, its considerable extent and depth are expected to cause significant earth deformation. The methods outlined in this study can be used to predict the magnitude of this deformation.

The ice sheet thickness history used in this study must be revised so that predicted and observed ancient shorelines are in agreement. The ICE-3G model adjusted over the Great Lakes region to improve fit to glacial Lake Oshkosh shorelines needs further modifications. For example the present rate of tilting over the Great Lakes, as indicated by lake gauge data (Mainville and Craymer 2005), would indicate a greater rate of tilt is occurring today over Lake Superior than predicted in our study (Fig. $12 b)$. Although it was not obvious at first, the errors introduced through uncertainty in the ice sheet thickness chronology are much greater than that resulting from omission of lake loading effects. Future work will use geophysical inversion theory to modify the ice sheet history, improving the fit of predictions to observations. This will provide an independent confirmation of the improved ICE-5G ice sheet chronology developed by Peltier (2004). 


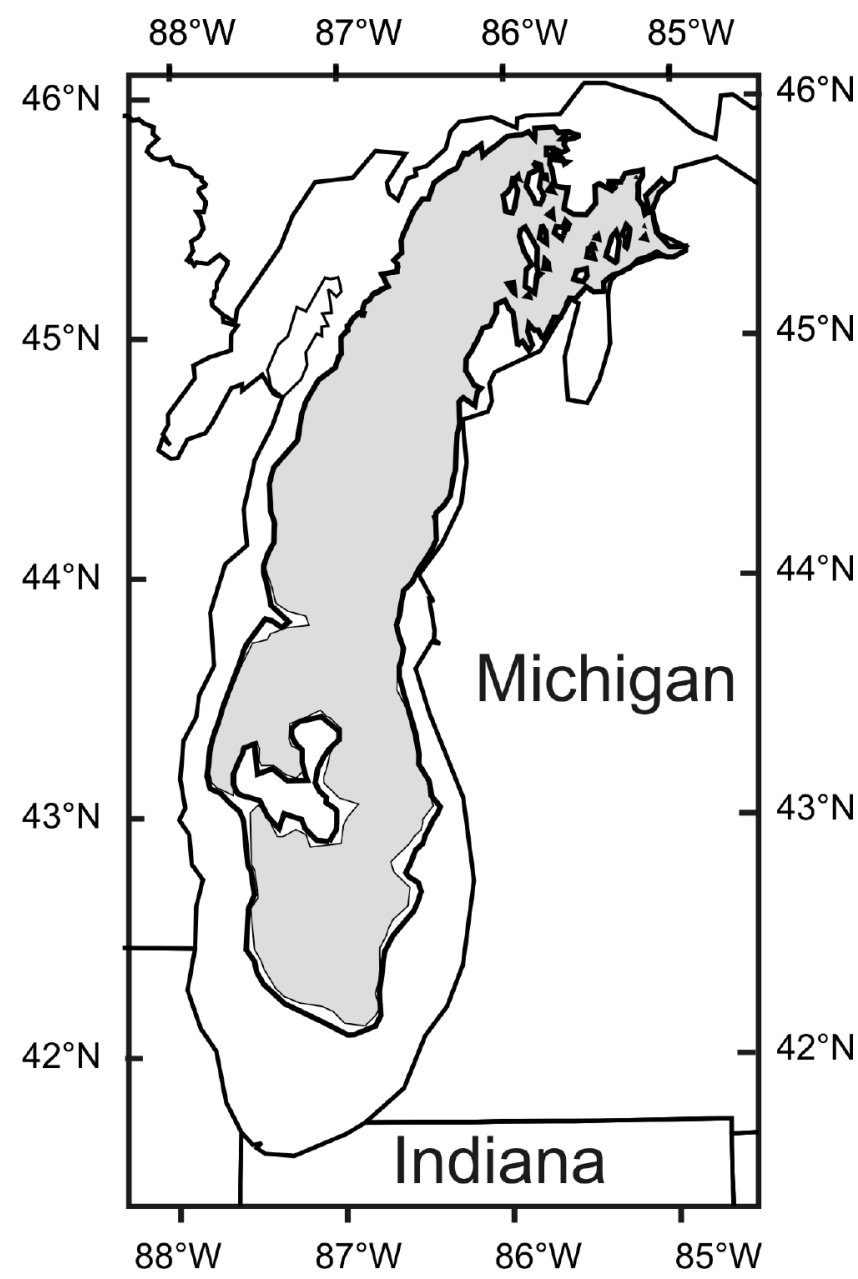

FIG. 13. Predicted lake shoreline positions for Lake Michigan 11,300 calendar years ago. Shaded region gives lake extent with only ice and ocean loads are included in the model. Thick line gives the more accurate shoreline position with lake loading also included.

\section{CONCLUSION}

It is possible to include the effect of water loading caused by the flooding of the Great Lakes region by proglacial, late-glacial, and postglacial lakes into models of glacio-isostatic adjustment. Given a present DEM and an assumed ice sheet history, numerical models can predict the lake history of the region for the past 30,000 years. No observations or assumptions such as the location of ancient shorelines or outlets are required in the calculation. Although water loading effects contribute only about 5 to $10 \%$ of the total deformation and so are of secondary importance in explaining the deforma- tion history and the lake history of the region, inclusion of these effects is necessary for precisely modeling the process.

\section{ACKNOWLEDGMENTS}

We gratefully acknowledge support from the National Science Foundation (NSF Grants EAR-0414012 and EAR-0624199), the National Aeronautical and Space Administration (NASA Grant NAG5-10348), the Wheaton College Alumni Association and the United States Geological Survey National Cooperative Geologic Mapping Program. Tom Hooyer of the Wisconsin Geological and Natural History Survey was a prime motivator in this work. Laura Toma provided timely help with implementation of the Terraflow extension to GRASS. Steve Colman and Shiyong Yu kindly provided their unpublished Lake Superior bathymetry data. Undergraduates Peter Stewart, Taylor Shipman, Chris Gregory, Matt Andresen, Lori McGuire, and Tanya Lubansky helped in early phases of this work. The manuscript benefited from the comments of two anonymous reviewers.

\section{REFERENCES}

Boulton, G.S., Smith, G.D., Jones, A.S., and Newsome, J. 1985. Glacial geology and glaciology of the last mid-latitude ice sheets. Geological Society of London Journal 142:447-474.

Broecker, W.S. 1966. Glacial rebound and the deformation of the shorelines of proglacial lakes. Journal of Geophysical Research 71:4777-4783.

Brotchie, J., and Silvester, R. 1969. On crustal flexure. Journal of Geophysical Research 74:5240-5252.

Cathles, L.M. 1975. The viscosity of the Earth's mantle. Princeton, NJ: Princeton University Press.

Clark, J.A., and Bloom, A.L. 1979. Hydro-isostasy and Holocene emergence of South America. In Proceedings of the 1978 International Symposium on Coastal Evolution in the Quaternary, K. Sugio, T.R. Fairchild, L. Martin, and J-M Flexor, eds., pp. 41-60. Sao Paulo, Brazil.

Clark, J.A., and Lingle, C.S. 1979. Predicted relative sea-level changes $(18,000$ years BP to present) caused by late-glacial retreat of the Antarctic Ice sheet. Quaternary Research 11:279-298.

Farrell, W.E., and Peltier, W.R. 1978. Global changes in post-glacial sea level: a numerical calculation. Quaternary Research 9:265-287.

Pranger, H.S., Walsh, J.K., and Primus, J.A. 1990. A numerical model of glacial isostasy in the Lake Michigan basin, In Late Quaternary history of the Lake Michigan basin. Geological Society of America Special Paper 251, A.F. Schneider and G.S. Fraser, eds., pp. 111-123. Boulder, Colorado. 
Hendriks, M., Timmermans, T.J., Struck, C., and Hilverda, K.J. 1994. Glacial isostatic deformation of the Great Lakes region. Geological Society of America Bulletin 106:19-31.

Clark, P.U. 1992. Surface form of the southern Laurentide Ice Sheet and its implications to ice-sheet dynamics. Geological Society of America Bulletin 104:595-605.

Colgan, P.M. 1999. Reconstruction of the Green Bay Lobe, Wisconsin, United States, from 26,000 to 13,000 radiocarbon years B.P. In Glacial Processes Past and Present, Geological Society of America Special Paper 337, D.M. Mickelson and J.W. Attig, eds., pp. 137-150. Boulder, Colorado.

Colman, S.M., Forester, R.M., Reynolds, R.L., Sweetkind, D.S., King, J.W., Gangemi, P., Jones, G.A., Keigwin, L.D., and Foster, D.S. 1994. Lake-level history of Lake Michigan for the past 12,000 years-The record from deep lacustrine sediments. J. Great Lakes Res. 20:73-92.

Dyke, A.S. 2004. An outline of North American deglaciation with emphasis on central and northern Canada. In Quaternary Glaciations-Extent and Chronology, Part II, J. Ehlers and P.L. Gibbard, eds., pp. 373-424. Amsterdam:Elsevier, Developments in Quaternary Science, Vol. $2 b$.

Fairbanks, R.G., Mortlock, R.A., Chiu, T-C., Cao, L., Kaplan, A., Guilderson, T.P., Fairbanks, T.W., and Bloom, A.L. 2005. Marine Radiocarbon Calibration Curve Spanning 0 to 50,000 Years B.P. Based on Paired ${ }^{230} \mathrm{Th} /{ }^{234} \mathrm{U} /{ }^{238} \mathrm{U}$ and ${ }^{14} \mathrm{C}$ Dates on Pristine Corals. Quaternary Science Reviews 24:1781-1796.

Farrell, W.E., and Clark, J.A. 1976. On postglacial sea level. Geophysical Jounal of the Royal Astronomical Society 46:647-667.

Fisher, D.A., Reeh, N., and Langley, K. 1985. Objective reconstruction of the Late Wisconsinan Laurentide Ice Sheet and the significance of deformable beds. Geographie physique et Quaternaire 39:229-238.

Goldthwait, J. W. 1908. A reconstruction of water planes of the extinct glacial lakes in the Lake Michigan basin. Journal of Geology 16:459-476.

Gutenberg, B. 1933. Tilting due to glacial melting. Journal of Geology 41:449-467.

Hansel, A.K., and Mickelson, D.M. 1988. A reevaluation of the timing and causes of high lake phases in the Lake Michigan basin. Quaternary Research 29:113-128.

Holcombe, T.L., Taylor, L.L., Reid, D.F., Warren, J.S., Vincent, P.A., and Herdendorf, C.E. 2003. Revised Lake Erie postglacial lake level history based on new detailed bathymetry. J. Great Lakes Res. 29:681-704

Hough, J.L. 1958. Geology of the Great Lakes. Urbana, Illinois: University of Illinois Press.

Hughes, T., Denton, G.H., Anderson, B.G., Schilling, D.H., Fastook, J.L., and Lingle, C.S. 1981. The last great ice sheet: A global view. In The last great ice sheets, G.H. Denton and T.J. Hughes, eds., pp. 263-317. New York: John Wiley and Sons.

Lambeck, K., and Nakada, M. 1990. Late Pleistocene and Holocene sea-level change along the Australian coast. Palaeogeogr., Palaeoclimatol. Palaeoecol. (Global Planetary Change Section) 89:143-176.

, Purcell, A., Johnston, P., Nakada, M., and Yokoyama, Y. 2003. Water-load definition in the glacio-hydro-isostatic sea-level equation. Quaternary Science Reviews 22:309-318.

Leverett, F., and Taylor, F.B. 1915. The Pleistocene of Indiana and Michigan and the History of the Great Lakes. U. S. Geological Survey Monograph 53.

Lewis, C.F.M., Blasco, S.M., and Gareau, P.L. 2005. Glacial isostatic adjustment of the Laurentian Great Lakes basin: using the empirical record of strandline deformation for reconstruction of early Holocene paleo-lakes and discovery of a hydrologically closed phase. Geographie Physique et Quaternaire 59:187-210.

Mainville, A., and Craymer, M.R. 2005. Present-day tilting of the Great Lakes region based on water level gauges. Geological Society of America Bulletin 117:1070-1080.

Mann, J., Leverington, D., Rayburn, J., and Teller, J., 1999, Modelling the volume and paleobathymetry of glacial Lake Agassiz. Journal of Paleolimnology 22:71-80.

Milne, G.A., and Mitrovica, J.X. 1996. Postglacial sealevel change on a rotating Earth: first results from a gravitationally self-consistent sea level equation. Geophysical Journal International 126:F13-F20.

, Mitrovica, J.X., and Davis, J.L. 1999. Near-field hydro-isostasy: the implementation of a revised sealevel equation. Geophysical Journal International 139:464-482.

Nunn, P.D., and Peltier, W.R. 2001. Far-field test of the ICE-4G model of global isostatic response to deglaciation using empirical and theoretical Holocene sea-level reconstructions for the Fiji islands, southwestern Pacific. Quaternary Research 55:203-214.

Peltier, W.R. 1974. The impulse response of a Maxwell earth. Reviews of Geophysics and Space Physics 12:649-669.

1994. Ice Age Paleotopography. Science 265:195-201.

. 1996. Mantle viscosity and Ice-age ice sheet topography. Science 273:1359-1364.

1998. The inverse problem for mantle viscosity. Inverse Problems 14:441-478.

1999. Global sea level rise and glacial isostatic adjustment. Global and Planetary Change 20:93-123. 2004. Global glacial isostasy and the surface of the ice-age earth: the ICE-5G (VM2) model and GRACE. Annual Reviews of Earth and Planetary Sciences 32:111-149. 
and Fairbanks, R.G. 2006. Global glacial ice volume and Last Glacial Maximum duration from an extended Barbados sea level record. Quaternary Science Reviews 25:3322-3337.

Sabadini, R., Lambeck, K., and Boschi, E. eds. 1991. Glacial isostasy, sea-level and mantle rheology. Boston: Kluwer Academic Publishers.

Spencer, J.W. 1888. Notes of the origin and history of the Great Lakes of North America. American Association for the Advancement of Science, Proceedings 37:197-199.

Tushingham, A.M., and Peltier, W.R. 1991. ICE-3G: A new global model of Late Pleistocene deglaciation based upon geophysical predictions of post-glacial relative sea-level change. Journal of Geophysical Research 96:4497-4523.
Tushingham, A.M., and Peltier, W.R. 1992. Validation of the ICE-3G model of Wurm-Wisconsin deglaciation using a global database of relative sea level histories. Journal of Geophysical Research 97:3285-3304.

Wu, P., and Peltier, W.R. 1983. Glacial isostatic adjustment and the free air gravity anomaly as a constraint on deep mantle viscosity. Geophysical Journal of the Royal Astronomical Society 74:377-450. and Peltier, W. R. 1984. Pleistocene deglaciation and the Earth's rotation: A new analysis. Geophysical Journal of the Royal Astronomical Society 76:202-242.

Submitted: 20 January 2007

Accepted: 11 June 2007

Editorial handling: Harvey Thorleifson 